\title{
Community psychiatry in Portugal: a critical review
}

\section{Внебольничная психиатрия в Португалии: критический обзор}

DOI: 10.17650/2712-7672-2020-1-1-49-59

\author{
Pedro Frias', Mariana Pinto da Costa ${ }^{1,2,3}$ \\ ${ }^{1}$ Hospital de Magalhães Lemos, Porto, Portugal; \\ ${ }^{2}$ Institute of Biomedical Sciences Abel Salazar (ICBAS), \\ University of Porto, Porto, Portugal; ${ }^{3}$ Unit for Social and \\ Community Psychiatry (WHO Collaborating Centre for Mental \\ Health Services Development), Queen Mary University of \\ London, London, United Kingdom.
}

\author{
Педро Фриас ${ }^{1}$, Мариана Пинто да Коста 1,2,3 \\ ${ }^{1}$ Госпиталь Магалэес Лемос, Порто, Португалия; \\ ${ }^{2}$ Институт биомедицинских наук им. Абеля \\ Саласара, Университет Порто, Порто, Португалия; \\ ${ }^{3}$ Подразделение социальной и общественной \\ психиатрии (Коллаборационный чентр ВОз по \\ развитию служб охраны психического здоровья), \\ Лондонский университет королевы Марии, Лондон, \\ Великобритания.
}

\section{ABSTRACT}

The mental health system in Portugal evolved from an institutional-centred system to a community-based system, a process which began in 1998 and has gathered pace since 2006.

The approval and implementation of the Portuguese Mental Health Law and the Portuguese National Mental Health Care Plan has contributed to the implementation of institutions and regulations aimed at decentralized, local and less restrictive models of care. The implementation and evolution process has been steady and gradual, introducing many of the envisioned changes whilst adapting existing mental health institutions and services.

The current article describes this transition process, attempting to identify the strengths and weaknesses of the Portuguese Mental Health System from a community-centred perspective.

\section{АННОТАЦИЯ}

Психиатрическая служба Португалии эволюционировала от институциональной во внебольничноориентированную систему, этот процесс начался в 1998 году и ускорился после 2006 года.

Утверждение и реализация в Португалии Закона о психической помощи и Национального плана охраны психического здоровья способствовали разработке нормативных актов и созданию учреждений в соответствии с моделью децентрализованной психиатрической службы, оказывающей помощь в наименее ограничительных условиях по месту жительства. Процесс внедрения и развития данной модели был планомерным и постепенным, с адаптацией существующих психиатрических учреждений и служб к запланированным изменениям.

В статье описывается процесс трансформации психиатрической службы Португалии и проводится анализ ее сильных и слабых сторон с точки зрения внебольнично-ориентированной парадигмы оказания помощи.

\section{Keywords: Portugal; Mental Health, Deinstitutionalization, Community Psychiatry, Mental Health Services Ключевые слова: Португалия, психическоездоровье, деинституционализация, внебольничная психиатрия, психиатрическая служба}




\section{INTRODUCTION}

According to data from 2017, mental health disorders were responsible for $12 \%$ of Disability Adjusted Life Years (DALYs) and $18 \%$ of Years Lived with Disability (YLDs). Depressive and anxiety disorders were placed in fourth and sixth place respectively, when considering all causes of disability and were responsible for loss of productivity and poorer social and developmental indicators. The population of Portugal has a prevalence of mental disorders in excess of $30 \%$, with depression and anxiety disorders amounting to $7.9 \%$ and $16.5 \%$ respectively [1, 2]. In particular, the time gap between symptom onset and treatment referral is considered too long [3]. Community-centred mental health care is regarded as more efficient and effective, allowing for continuity of care and support to empower patients by treating them in the least restrictive way possible, resulting in better outcomes [4].

The history of mental health care in Portugal is similar to that of other European countries, with deinstitutionalization efforts beginning in the latter half of the $20^{\text {th }}$ century and becoming law in 1998 . Since then, the mental health system in Portugal has been organized into local and regional institutions, with the remaining psychiatric hospitals undergoing a transitional process to provide general, decentralized health care services and a long-term care network, contributing to and supporting recovery, reintegration and the rehabilitation of capabilities in a community-based setting. The transitional process still faces challenges today, however, solutions have been suggested. In the last few years, important steps have been undertaken to fully complete the transition to community-based care.

This article aims to explore and synthetize the evolution of the transitional process in Portugal, from institutionalcentred mental health care to community-based health care, identifying challenges and proposed solutions in order to reinforce its effective implementation.

\section{METHODS}

The authors performed a critical search of policy and legislative documents from the official reports of national and international institutions and articles regarding community mental health in both Portuguese and English languages.

The review was conducted in February 2018 and updated in April 2020. Combinations of the following terms were searched: "Mental Health Care", "Community Mental Health Care", "Community Psychiatry", "Community Psychiatry in Portugal", "History of Community Psychiatry in Portugal", "Challenges to Community Psychiatry in Portugal", "Mental Health Portugal", "Psychiatry in Portugal", "Financial Models Mental Health". The following databases, search engines and websites were used - the Portuguese Official Gazette and electronic databases: Medline, Pubmed and GoogleScholar.

The publications were selected according to their relevance and content, and all publications were screened and discussed among the authors. Publications were excluded if they were deemed not to contribute with relevant information to the objectives of this article.

\section{RESULTS}

The authors found a total of 42 publications, including legislation and policy documents or reports, and scientific peer-reviewed articles concerning the provision of community mental health care in Portugal.

The three main themes covered in these publications related to: mental health care systems and institutions in Portugal, the history of mental health care in Portugal and challenges to implementing community psychiatry in Portugal.

\section{History of Mental Health Care in Portugal}

Community psychiatry in Portugal reflects the evolution of thought and knowledge in relation to the issues of the mind and its ailments. Mental health care underwent a predominantly institutional model during the nineteenth century, and the first mental health law dates from 1889. The twentieth century was characterized by the construction and capacitation of large psychiatric hospitals, in order to standardize treatment and keep mental health patients isolated from the rest of society [5-7].

The first deinstitutionalizing efforts can be traced back to 1927, with Sobral Cid arguing for the replacement of asylum centres with specialized centres, focusing on prevention, treatment and reintegration. A law passed in 1945 advocated a 'hygienist and prophylactic approach', instructing the construction of a hospital Hospital Magalhães Lemos - with a pavilion-oriented disposition as an important intermediate step.

The psychopharmacological "revolution" of the 60s, allied to the evolution in thinking, allowed for a paradigm 
shift that culminated in the mental health law of 1963 , deemed as the first legislative step towards the direction of community-based mental health care [5, 7-10]. The '70s, '80s and '90s saw a slow but progressive march towards decentralization, with the creation of the Portuguese National Health System (NHS) in 1979 with the reinforcement of primary care and successive mental health plans and legislation enforcing a less vertical, hospital-centred model [10-12].

Since the last decades of the twentieth century, and primarily after 1998, Portugal has gradually been implementing a transition from an institutional model, in which central and psychiatric hospitals were the mainstay in mental health care, to a decentralized, community-based system.

In 1998, the approval of a new mental health law, later complemented by a joint decree ( $n^{\circ}$ 407/98) from the Ministries of Health and Work and Welfare [7, 1315], organized mental health care, prioritizing care at community level, in the least restrictive environment possible. Inpatient units, focused on more serious and acute illnesses were preferably annexed to general hospitals while outpatient treatment, where possible, was provided in local health centres. Psychosocial rehabilitation was administered through residential institutions, day-care centres and professional training units, adapted to each patient's level of autonomy and needs [15]. Within this model, the Local Mental Health Services (LMHS) constituted the basic units, whereas the psychiatric hospitals, still in existence despite this reorganization, were responsible for providing both local care, as well as specialized region-wide services, offering an adequate level of care for patients unable to be treated in general hospital units [13-15].

Portugal, as a subscriber to the 2005 World Health Organization's (WHO) Mental Health Action Plan for Europe [16] and Mental Health Declaration for Europe [17] has reaffirmed its pledge to develop community-based services, acknowledging the importance of "recovery and inclusion into society of those who have experienced serious mental health problems" and committing, among other things, to offering mental health patients treatment and comprehensive care in a wide range of settings, while establishing partnerships and cooperation across regions and sectors, both on a geographical and an organizational level $[10,16,17]$.
Established in 2006, the National Council for Mental Health (NCMH) produced a report on mental health in Portugal and the National Mental Health Plan (NMHP) 2007-2016, identifying the problems in implementing certain objectives of the 1998 law and proposing solutions $[4,15]$.

This document resulted in more focus on deinstitutionalizing patients successfully and promoting their integration into the community. One of the primary concerns of the NMHP has been "integrating mental health care in primary care, guaranteeing continuity of care, starting inpatient admissions, followed by rehabilitation and domiciliary assistance" [4], stating that no central institution should be closed until adequate community-based solutions have been created, capable of accommodating patients previously referred to that institution, thereby significantly encouraging the development of community-centred services $[10,15,18]$.

The approval of Decree-Law 8/2010 in January 2010, established the National Programme for Continued Care in Mental Health for patients with severe mental illness. In 2017, through the Order 1269/2017, approval was granted to create pilot projects in community-based, long-term, mental health care $[19,20]$.

\section{Mental Health Care System and Institutions in Portugal}

Portugal is a European country, situated in the south-west of the Iberian Peninsula, with a population of around 10 million. It is composed of 18 districts and two autonomous regions, corresponding to the archipelagos of Madeira and the Azores. From an organizational point of view, the continental part of the country is divided into five health regions, administered by the regional health administrations (Figure 1), responsible for granting access to health care, while assuring the compliance of health policies and programmes as well as executing health care policies, coordinating planning measures and supporting and evaluating public health institutions in their areas of intervention [21-23].

Mental health services are organized into regional and local services. Local services form the basis of the national mental health care system in Portugal and are desirably connected with primary health care and other institutions, providing essential mental health care in both inpatient and outpatient settings and assuring continuity of care by 
linking with other programmes and services. They can be organized in a similar way to departments of services in general hospitals (Figure 2).

Regional services are responsible for supporting and complementing local services, among other duties $[1,13,14,24]$. The document that regulates and creates mental health home treatment teams, described the aforementioned components as interdependent, since each level and context of care needs to be optimized to allow for quality of care and an adequate transition to a more decentralized health care model.

The LMHS, the basis of mental health care in Portugal are organized according to the numbers of the population for which they are responsible. They are tasked with providing mental health care for their respective population in the least restrictive way possible, maintaining inpatient and day hospital treatments [1,25]. Psychiatric hospitals and regional institutions are also responsible for

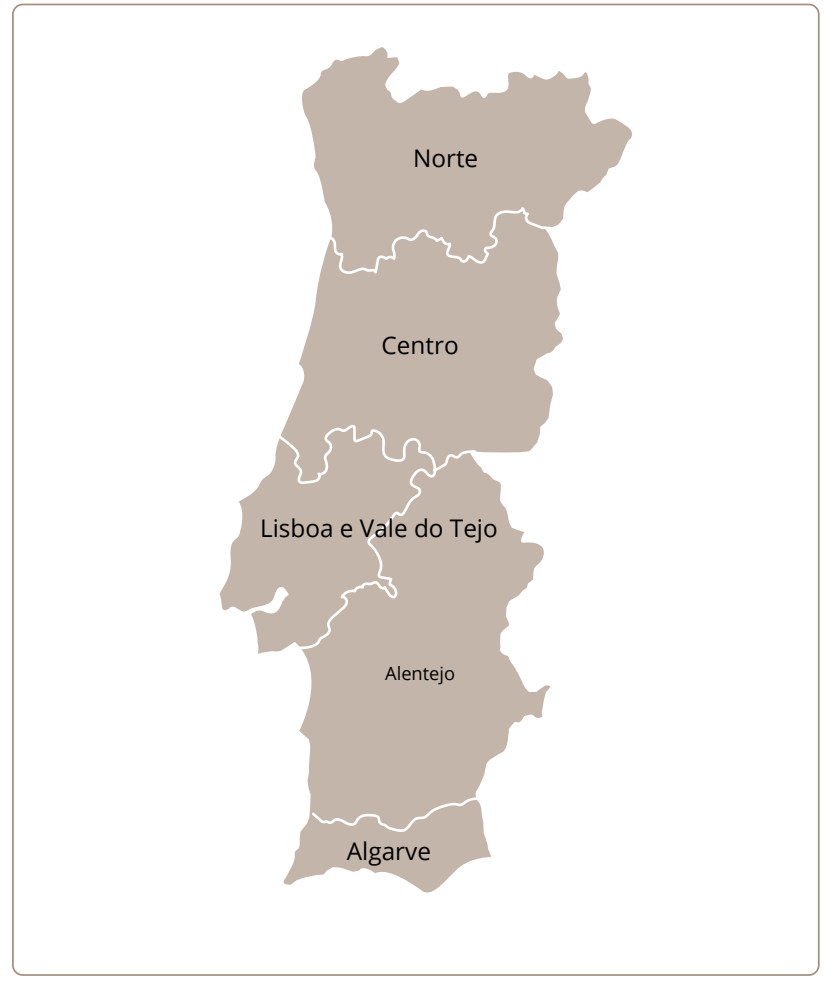

Figure 1. Map of Portugal

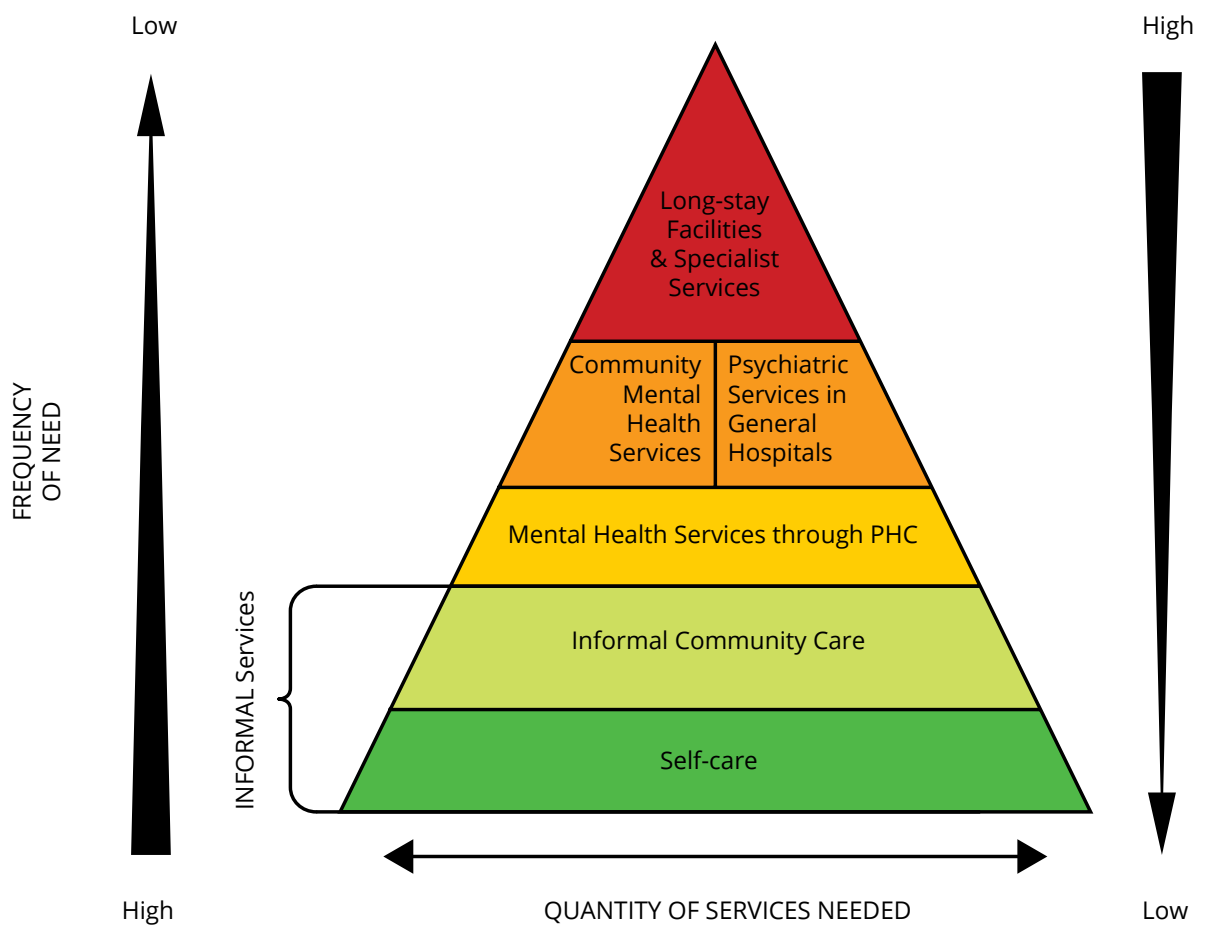

Figure 2. Portugal Mental Health Services in a desirable future 
ensuring regional responses to problems that require predominately institutional solutions and answers for prolonged illness [1].

The mental health home treatment teams are foreseen as an important component of the LMHS [26]. Their objectives encompass the treatment of patients with severe mental illness following a case management review, while maintaining the connection to primary care and support for less severe, and more common mental health problems, providing support for the elderly population and coordinating prevention programmes in relation to suicide and depression. They are composed of multidisciplinary teams with active participation on the part of nurses and other nonmedical professionals [1, 26].

The rehabilitation and psychosocial reintegration services are delivered primarily through three different institutions that comprise the National Network for Continued Mental Health Care in conjunction with the LMHS and the National Network of Integrated Care $[19,27]$. Residential units, socio-occupational units and domiciliary support teams represent a continuum of patient autonomy levels, offering care in residential and ambulatory settings accordingly. Comprised of psychiatrists, mental health and general nurses, psychologists, social workers, occupational therapists and legal advisors, these different services can adapt to changing patient needs, and are centred on improving social and community-wide integration, empowerment and effective recovery, allowing the patient to live life to the full and to contribute to society [28]. Firstly, the residential units function as community-integrated residences for people with mental health disorders, granting them access to specialized mental health care, medical and nursing care, psychosocial support, rehabilitation and community integration [19]. They also aim to provide psychoeducation to family members or caregivers, as well as providing transportation for patients to other health care facilities when required. Residential units are divided into subtypes, ranging from autonomous training residences to maximum support residences [29]. Secondly, the socio-occupational units are located in the community and designated to patients with mild to moderate psychosocial dysfunction, and social, occupational or relational impairment. They promote autonomy, emotional stability and social participation, with the objective of providing social, familiar and professional integration and stability [19, 28]. Thirdly, the home treatment teams act on a domiciliary level to help supervise and manage medication, ensure regular support in terms of personal care and daily activities and oversee financial and household management [19]. They are, by definition, connected and coordinated by residential units, socio-occupational units, local primary care structures or the LMHS [27].

Patients with chronic and clinically-stable, severe mental illness, including those with learning and intellectual disabilities, resulting in psychosocial disability, can be referred by any health care professional to institutions in the National Network of Continued Mental Health Care [27]. The patient's admission criteria are verified by their local mental health care service, primary care unit, or in the case of children or adolescents to child and adolescent mental health care units, their orientation being defined in accordance with their needs, following a case management review.

Funding for mental health services is primarily granted through government funds, namely the health budget. Primary and secondary health care levels are financed according to specific indexes reflecting service usage, mainly inpatient treatment and outpatient consultations; long-term and rehabilitation health care receive a sum mainly related to inpatient treatment days per patient [30]. Specific funding for community-based institutions has been introduced this year, with regard to the pilot LMHS [31]. Private Non-Governmental Organizations (NGOs) and companies can also manage and provide financing for institutions, which are integrated into the National Network of Integrated Mental Health Care.

Currently there are $40 \mathrm{LMHS}$ divided into administrative regions (16 in the North, seven in the Centre, 13 in Lisbon, four in Alentejo and two in the Algarve region) [18], and two mental health services in psychiatric hospitals (Hospital de Magalhães Lemos in Porto and Centro Hospitalar Psiquiátrico de Lisboa in Lisbon) [23].

It should also be noted that, along with the evolution observed in general mental health services throughout the years and specifically since 1998, Portugal has implemented and reinforced a strong and decentralized, addiction-oriented division of its mental health services. These services are structured around local intervention units (integrated response centres; alcohol units, dishabituation units and therapeutic communities) distributed by region. Each integrated response centre 
is responsible for the prevention and treatment of drug or alcohol-related disorders, with an emphasis on reducing harm and reintegrating patients by working with specialized teams (Treatment Team) and decentralized outpatient treatment programmes [32] .

Similarly, child and adolescent psychiatry has seen a gradual paradigm shift towards a decentralized model. In general terms, psychiatry inpatient units and emergency services are devolved to regional level services (of which there are four), while outpatient units and other services are provided by departments or units, connected to general hospitals (totalling 30, with nine local departments and 21 units) [33].

Cooperation with primary health care and other community-based institutions is deemed fundamental for the multidisciplinary teams of child and adolescent psychiatry, and several departments both local and regional, have functioning community-centred teams, which enforce ongoing protocols with community and social organizations, such as schools and caregiving institutions [33]. The National Network of Continued Mental Health Care also provides specific long-term, integrated care facilities, and its implementation and evolution accompanies that of adult mental health care [33, 34]. In relation to old age psychiatry, Portugal has not implemented a specific national, community-centred response

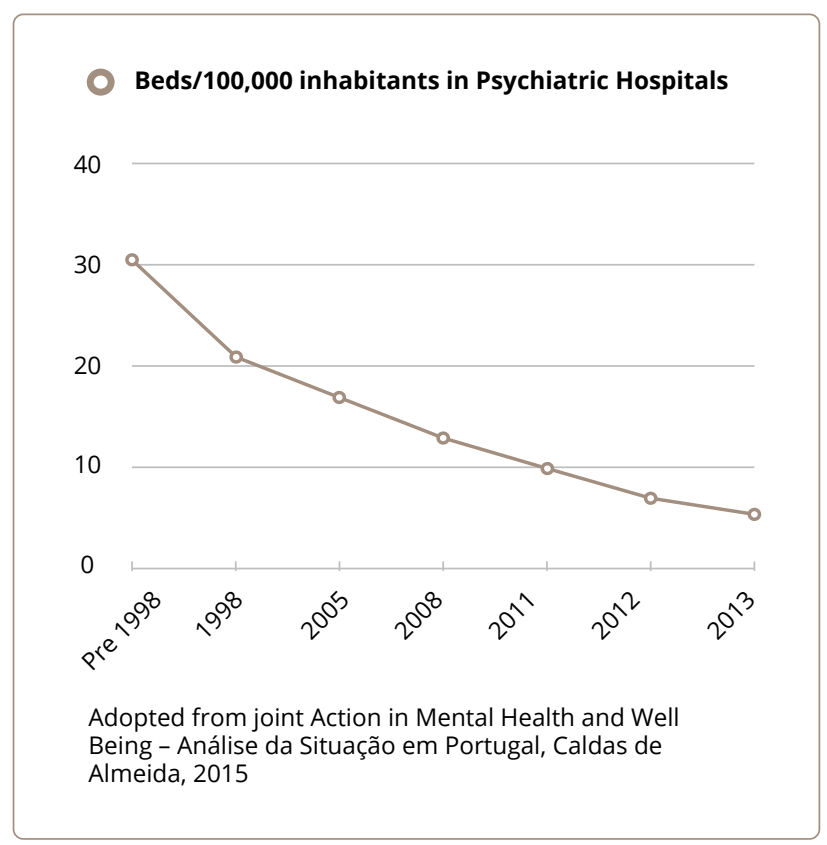

Figure 3. Beds/100,000 inhabitants in Psychiatric Hospitals in this area. Some mental health services have specific inpatient or outpatient units devoted to the older population, however, a widespread differentiated response is still absent.

The number of institutions integrating the National Network of Continued Mental Health Care has increased since 2017. Data from 2019 indicate that there are 140 residential units of different types, 85 socio-occupational units and 24 domiciliary support teams, mainly in the North, in Lisbon and in the Tejo Valley regions [1].

During the last few years, according to available data, there has already been a transition from a centralized model to more decentralization, evidenced by the decrease in the number of beds per 100,000 inhabitants in psychiatric hospitals (Figure 3), the reduction in public residential availability, which has been transferred to the social sector (Figure 4) and the increase in inpatient capacity in general hospitals (owing to the closure of Hospital Miguel Bombarda, Centro Psiquiátrico de Recuperação de Ames and Hospital do Lorvão in 2009) and LMHS (Figure 5) with around 10 beds per 100,000 inhabitants in 2015 [8]. In $2013,6 \%$ of day hospital consultations were offered in a community setting [35], while data from 2017 show a global increase in consultations with patients treated in day hospitals (Figure 6).

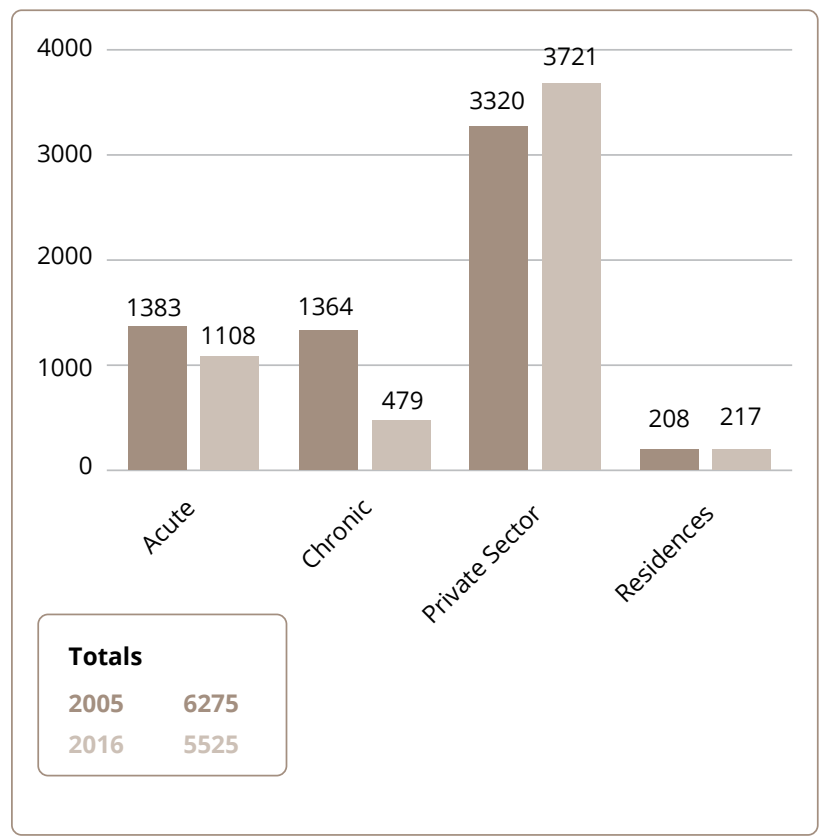

Figure 4. № of beds (National) 


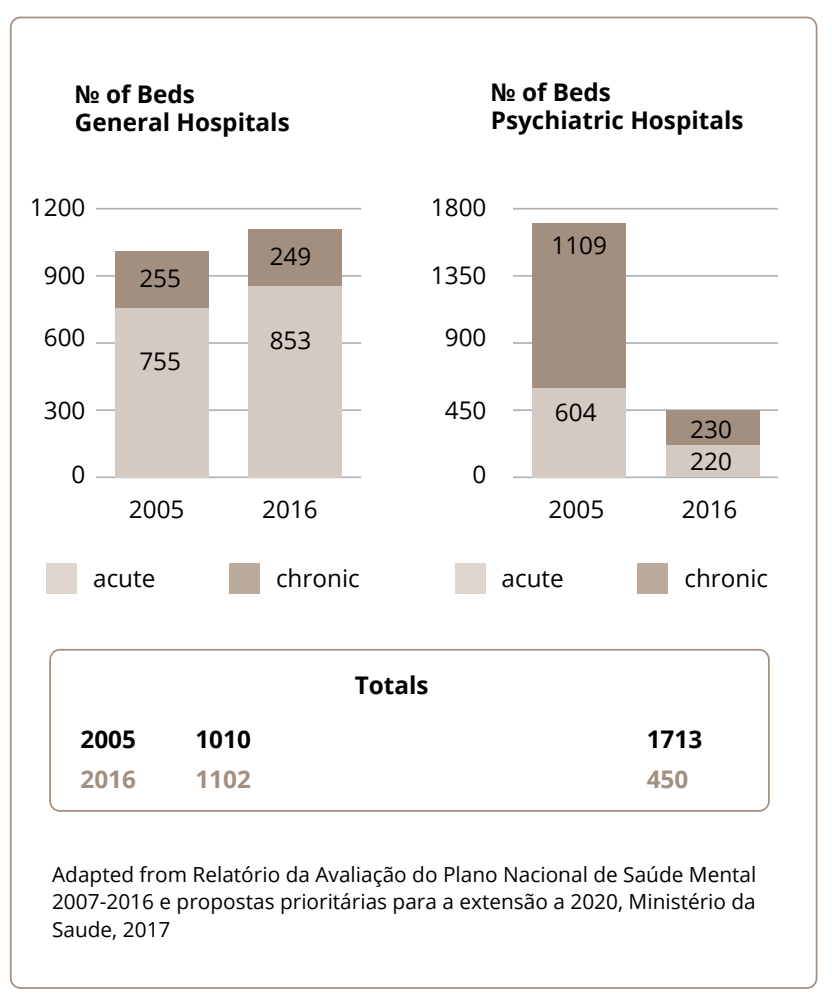

Figure 5. № of Beds: General vs. Psychiatric Hospitals

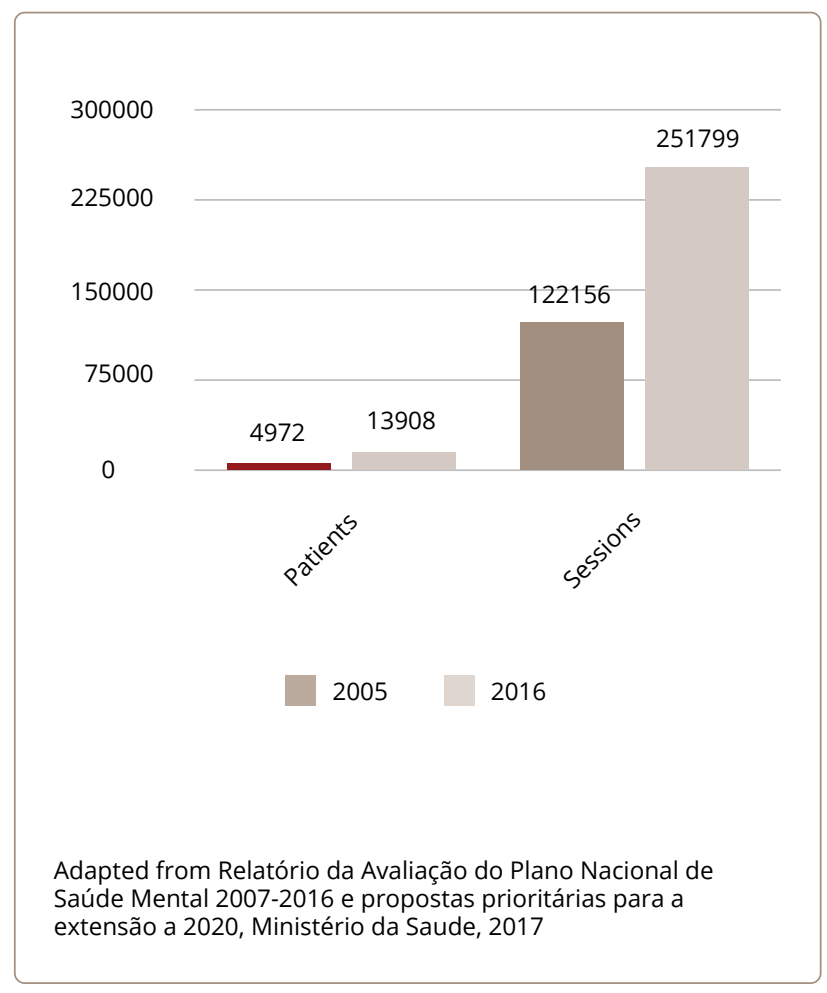

Figure 6. Day Hospitals - National Totals
Challenges to Implementing Community Psychiatry in Portugal

A number of challenges have been highlighted in various reports by different authors, which can generally be distinguished between a lack of funding or pertaining to other organizational barriers.

First and foremost, several reports have identified that the lack of funding for community-based mental health care services is a crucial barrier to its development. In a report published in 2019, the National Health Council analysed the evolution and current situation of mental health care in Portugal, identifying the scarcity of financial and human resources as a serious threat to the system's development. Payment mechanisms are also considered by the National Health Council as major barriers to the implementation of community-based mental health care. In fact, current payment models reward hospitals for their medical interventions and admissions, without enforcing community-based interventions and failing to create financial incentives to promote their implementation. The coexistence of different payment modalities and the absence of incentive-based payments for treating mental disorders in the primary care system, together with poor communication between different levels of care, can contribute to the asymmetries in patients' treatment [1, 8, 30, 35-37].

Secondly, many authors highlight the poor communication between the different levels of care as a barrier to this transition process, namely between mental health services and primary care, but also between these and the National Network for Continued Mental Health Care, while emphasizing the persistence of a primarily hospital-centred model [8, 38].

An additional hindrance concerns the transition process of moving acute inpatient departments from psychiatric hospitals to LMHS in general hospitals, which is still to be completed. A number of services specified in the legislation are yet to be implemented equally throughout the territory of Portugal, leading to asymmetries in coverage. As an example, some authors have pointed out the lack of operating residential units, capable of granting housing and basic care to chronic mental health patients, previously housed in psychiatric hospitals. In relation to the specific rehabilitation and reintegration programmes, which are being planned, there is still much to be done. Vocational programmes, professional training and the creation of residential 
institutions are still scarcely implemented. Estimates from 2015 suggest that of the 4000 to 5000 patients expected to be integrated into the socio-occupational units or residential units, only around 900 were effectively housed [1, 10, 19, 30, 35].

Another concern is the lack of specialized personnel, mainly specialized nurses, as well as limited training of other, non-health professionals to deal with mental health patients $[8,39]$.

The engagement of patients and caregivers in the transition process is regarded as an important indicator [28]. An article from 2015 analyses the role of patients and family members/caregivers in the deinstitutionalization process. The authors highlight that during the institutionalization process, the opinions of family members and patients are taken into account, albeit with asymmetries. Data on the specific nature of patients' and caregivers' roles in the transition process are scarce and somewhat divergent, however, patients' and caregivers' associations have increasingly more visibility in the public space, advocating and promoting discourse in relation to a range of mental health issues $[8,10]$.

A number of solutions to overcome these barriers have been suggested, some of which have been implemented within certain services in Portugal.

Firstly, a new payment model for community-based mental health has recently been proposed. This entails a combination of elements of various payment schemes in order to attenuate their respective weaknesses, and implement best practices. This aims to encourage the early detection and treatment of mental health disorders, a community-based follow-up in cases of severe mental illness and the treatment of moderate depression within the primary health care system [37].

Another important matter relates to psychiatry training in Portugal, which comprises a three-month mandatory placement within community psychiatry. Still, inpatient practice is a much longer mandatory placement, with a duration of at least 24 months currently [40]. In Portugal, the views of psychiatric trainees have previously been taken into consideration to improve training, and this should perhaps be extended to the sphere of community psychiatry education. For example, in a survey conducted by psychiatric trainees in 2011, trainees in Portugal expressed the need for forensic psychiatry to be an obligatory rotation in their training programme and as an area in which to specialize [24]. These views were later acted upon by the Portuguese Medical Council Association, which introduced forensic psychiatry as a mandatory rotation, and created the subspeciality of forensic psychiatry. Equally, if community psychiatry training is strengthened and extended into the psychiatric trainees' programmes, this would allow future psychiatrists to be better prepared for this model of care, contributing to its effective implementation earlier, while still trainees.

In order to improve and follow the WHO's recommendations, a thorough regional assessment of needs of both mental health patients and available trained personnel is required. Subsequently, it is vital to reform the mental health payment model that considers specific activities and population covered, as well as productivity-related incentives for professionals. This would strengthen the viewpoint proposed in 2009 in the consensus document for community mental health teams, while granting intermediate institutions, such as LMHS autonomy in terms of decision-making and finances, enabling them to monitor and address community needs, quality indicators and the assembly of communitybased institutions, stipulated by law [26, 37].

In a 2008 publication, Thornicroft et al. describe a series of common challenges faced in the implementation processes of community-based psychiatry, primarily in Italy and England, while also describing issues central to the development of mental health services. Similar to Thornicroft, various Portuguese authors and institutions have highlighted challenges to the transition process, as described in this paper $[10,15,27,30,35,38]$. Some of these challenges, listed in Table 1, also concern the transition process in Portugal [41].

The proposed solutions relate to general and organizational aspects, not necessarily related to mental health issues, as well as to staff-related challenges, less commonly documented in the literature, yet prevalent in every transition process [42].

In its report from 2019, the National Health Council proposed a series of priority measures to be undertaken. Among them, and following recommendations from the National Mental Health Plan, was the recommendation that the integration of mental health care within primary care, should be viewed as an absolute priority and that integration models should take into account local and 
regional specificities. With regard to long-term care, it was deemed as essential to correct asymmetries, to complement the network with its most needed typologies, such as moderate and maximum support residences. It was also considered important to reinforce the coordination and integration of care, including supporting the primary health care treatment of less severe mental health illnesses through financial incentives, increasing staff numbers and training. Reinforcing community-based social institutions could also be beneficial in strengthening community-based mental health care.

Recently in 2020, community mental health teams were created and regulated in the various administrative health regions, both for adult and for child and adolescent psychiatry. These teams are organized according to a systemic and holistic model, ensuring communitycentred treatment in conjunction with different levels of care and professional classes, supporting patients' rehabilitation and reintegration, while promoting mental health and preventing illness at an individual level, as well as in a broader context [31]. The teams are allocated to their LMHS and function within decentralized facilities; their multidisciplinary constitution is defined in the decree, as well as their specific objectives and the services they provide (outpatient consultation, psychotherapies and individual psychological follow-ups, group therapy and interventions, domiciliary visits, social support, patient-centred community interventions, etc.). These teams were created in order to combat the perceived disparities between different mental health services and regions, serving as pilot projects and following evaluation, shall be implemented as a uniform model for application in all LMHS [31]. This is a really important step forward, as it will enable the standardization of community-based action within LMHS, as well as providing specific funding for these projects and allowing for effective analysis to inform future developments [31].

\section{CONCLUSIONS}

The Portuguese model of community-based care was adopted mainly from the historical evolution and tendencies of other European countries. Although community psychiatry in Portugal has already been implemented, it is undergoing continuous improvement and much still needs to be done to perfect it.

The barriers to its effective implementation range from a lack of adequate personal and financial resources to poor communication between the different levels of care and services.

Nevertheless, steps are being taken to strengthen and further implement community psychiatry within the country. Among these measures are the proposals concerning payment models and the attempts to implement case-management models in this area.

The gradual, informed and unrelenting adoption of such measures should eventually contribute to implementing effective community-based mental health care in Portugal.

Table 1. Barriers and Solutions in relation to implementing community-based psychiatry

\begin{tabular}{|l|l|}
\hline Barriers & Solutions \\
\hline Inadequate Financing & $\begin{array}{l}\text { Introduce new payment models targeting community-based } \\
\text { mental health care }\end{array}$ \\
\hline $\begin{array}{l}\text { Routine changes in staff transitioning to community-based health } \\
\text { care }\end{array}$ & $\begin{array}{l}\text { Implement clear timetables, frequent staff meetings, clear } \\
\text { communication between different levels of decision-making }\end{array}$ \\
\hline Centralized decision makers & $\begin{array}{l}\text { Empower local and regional institutions, enabling them to enforce } \\
\text { policies adapted to their reality }\end{array}$ \\
\hline System Rigidity & $\begin{array}{l}\text { Enable community-based services to adopt more flexible } \\
\text { practices, in conjunction with LMHS and regional institutions }\end{array}$ \\
\hline $\begin{array}{l}\text { Lack of training/education } \\
\text { Anxiety and uncertainty affecting staff transitioning from a } \\
\text { hospital-centred model to a community-based model }\end{array}$ & $\begin{array}{l}\text { Increase training duration for psychiatry trainees and other } \\
\text { mental health professionals }\end{array}$ \\
\hline
\end{tabular}


This process aims to integrate mental health services into primary care, develop a psychosocial network and provide training for mental health staff, whilst addressing quality indexes.

Author Contributions: Pedro Frias and Mariana Pinto da Costa conceived the study and wrote the paper.

Funding: The authors declare that there was no funding for this work.

\section{Conflict of Interest: The authors declare that they have} no conflict of interest.

\section{Correspondence to:}

\section{Mariana Pinto da Costa}

mariana.pintodacosta@gmail.com

\section{References}

1. Conselho Nacional de Saúde. Sem mais tempo a perder - Saúde mental em Portugal: um desafio para a próxima década [National Health Council. No Time to Lose - Mental Health in Portugal, a Challenge for the next Decade] [Internet]. Lisboa: CNS; 2019 [cited 2020 Aug 15]. Available from: https://fronteirasxxi.pt/wp-content/ uploads/2020/02/"Sem-mais-tempo-a-perder"-CNS-2019.pdf Portuguese.

2. Caldas-de-Almeida JM, Xavier M, Cardoso G, et al. Estudo epidemiológico nacional de saúde mental: 10 relatório [National Epidemiological Mental Health Study - 1st Report]. Lisboa: Faculdade de Ciências Médicas, Universidade Nova de Lisboa [Internet]. 2013 [cited 2020 Aug 15]. Available from: http://www. $\mathrm{fcm}$.unl.pt/main/alldoc/galeria_imagens/Relatorio_Estudo_SaudeMental_2.pdf Portuguese.

3. Carvalho ÁD, Mateus P, Nogueira PJ, Farinha CS, Oliveira AL, Alves MI, Martins J. Portugal Saúde Mental em Números, 2015. Portugal Saúde Mental em Números [Internet]. 2015: 5-113 [cited 2020 Aug 18]. Available from: https://dependencias.pt/images/files/ Portugal.pdf Portuguese.

4. de Ministros PPDC. Plano Nacional de Saúde Mental 2007-2016 [Internet]. Diário da Republica; 2008 (47) [cited 2020 Aug 18]. Available from: https://www.adeb.pt/files/upload/paginas/ Plano\%20Nacional\%20de\%20Saude\%20Mental.pdf Portuguese.

5. de Melo S, Guilherme M, Guilherme F. [Community Psychiatry in the Historical Evolution of Psychiatry]. Análise Psicológica. 1981;31:357-63. Portuguese.

6. Pereira JMM. [Psychiatry in Portugal: Protagonists and Conceptual History (1884-1924)]. Faculdade de Letras da Universidade de Coimbra. [Internet]. 2015 [cited 2020 Aug 15]. Available from: http://hdl.handle.net/10316/29514 Portuguese.

7. Alves F, Ferreira-da-Silva L. [Psychiatry and Community: Reflexive Elements]. Actas do V Congresso Português de Sociologia. Sociedades Contemporâneas: Reflexividade e Acção. Associação Portuguesa de Sociologia (APS). 2004 May:56-64. Portuguese.

8. Caldas-de-Almeida JM, Mateus $P$, Tomé $G$, et al. Joint Action in Mental Health and Well Being: Towards Community-Based and
Socially Inclusive Mental Health Care [Internet]. 2015 [cited 2020 Aug 18]. Available from: https://ec.europa.eu/health/sites/health/ files/mental_health/docs/2017_towardsmhcare_en.pdf

9. Governo de Portugal [Internet]. Série I de 3 de Abril de 1963, no 79/1963, 1963 [cited 2020 Aug 10]. Available from: https://dre.pt/ legislacao-consolidada/-/lc/75088193/199907260100/73318787/ diploma/indice Portuguese.

10. Palha F, Costa N. [Trajectories on Mental Health Care. Part 1 - The psychiatric "deinstitutionalization" process: from an objective analysis of facts to patients', caregivers' and technicians' perspectives] [Internet]. Porto: ENCONTRAR+SE; 2015 Mar [cited 2020 Aug 10]. Available from: https:// www.encontrarse.pt/wp-content/uploads/2016/04/projectos concluidos_tcsm1.pdf Portuguese.

11. Madianos MG. Recent advances in community psychiatry and psychosocial rehabilitation in Greece and the other southern European countries. Int J Soc Psychiatry. 1994 Autumn;40(3):157-64. doi: 10.1177/002076409404000301. PMID: 7822108.

12. Cardoso G, Teresa M. [General Hospital Based Psychiatric Community Services: A Portuguese Model]. PsiLogos, 2009;6(2)/7(1-2): 54-66. Portuguese.

13. Governo de Portugal. [Law $36 / 98$ of 24 th July 1998 , Mental Health Law]. [Internet]. 1998. [cited 2020 Aug 15]. Available from: https://data.dre.pt/eli/lei/36/1998/07/24/p/dre/pt/html Portuguese.

14. Ministérios da Saúde do Trabalho e da Solidariedade, Despacho conjunto $n^{\circ}$ 407/98 [Internet]. 1998; 8328-32 [cited 2020 Aug 15]. Available from: http://www.seg-social.pt/ documents/10152/35243/Desp_C_407_98 Portuguese.

15. Cardoso G, Papoila A, Tomé G, Killaspy H, King M, Caldasde-Almeida JM. Living conditions and quality of care in residential units for people with long-term mental illness in Portugal-a cross-sectional study. BMC Psychiatry. 2016 Feb 20;16:34. doi: 10.1186/s12888-016-0743-7. PMID: 26897745; PMCID: PMC4761132.

16. WHO European Ministerial Conference on Mental Health (1st: 2005: Helsinki, Finland) \& World Health Organization. Regional Office for Europe [Internet]. Mental health action plan for Europe: facing the challenges, building solutions: First WHO European Ministerial Conference on Mental Health, Helsinki, Finland 12-15 January 2005. Copenhagen: WHO Regional Office for Europe. [cited 2020 Aug 15]. Available from: https://apps. who.int/iris/handle/10665/107627

17. World Health Organization [Internet]. Mental Health Declaration for Europe - Facing the Challenges, Building Solutions; WHO Copenhagen. 2005. [cited 2020 Aug 15]. Available from: https:// www.euro.who.int/_data/assets/pdf_file/0008/96452/E87301.pdf

18. Direção Geral da Saúde [Internet]. Ministério da Saúde. Programa Nacional para a Saúde Mental. Programa Nacional para a Saúde Mental 2017 [General Health Directorate. Ministry of Health. National Programme for Mental Health. National Mental Health Plan 2017]; 2017 [cited 2020 Aug 18]. Available from: https://www.dgs.pt/em-destaque/relatorio-do-programanacional-para-a-saude-mental-2017.aspx Portuguese.

19. Ministério da Saúde [Internet], Decreto-Lei n8/2010 (Jan 28, 2010) [cited 2020 Aug 18]. Available from: https://data.dre.pt/eli/ dec-lei/8/2010/01/28/p/dre/pt/html Portuguese.

20. Ministérios das Finanças [Internet], Trabalho, Solidariedade e Segurança Social e Saúde [Ministries of Health, Finance, Work, Solidarity and Social Security], Despacho n 1269/2017, 2443- 
2444 (2017) [cited 2020 Aug 18]. Available from: https://dre.pt/ home/-/dre/106396948/details/maximized Portuguese.

21. Ministério da Saúde [Internet], Decreto-Lei 22/2012, 513-516 (2012) [cited 2020 Aug 18]. Available from: https://data.dre.pt/eli/ dec-lei/22/2012/01/30/p/dre/pt/html Portuguese.

22. Pordata - Base de Dados Portugal Contemporâneo[Internet]. BI de Portugal [Portugal's Identity Card]. 2020 [cited 2020 Aug 18]. Available from: https://www.pordata.pt/Portugal Portuguese.

23. Programa Nacional para a Saúde Mental [Internet]; Direção Geral de Saúde [General Health Directorate]. Saúde Mental. 2020 [cited 2020 May 7]. Available from: https://saudemental.covid19.minsaude.pt/ Portuguese.

24. Pinto da Costa M, Moscoso A, Marques JG. Community Psychiatry: Training and Practice in Portugal [poster presentation] [Internet]. 2012 [cited 2020 Aug 12]. Available from: https://www. researchgate.net/publication/337448726_Community_Psychiatry_ Training_and_Practice_in_Portugal

25. Direção Geral de Sáude. Organização de Cuidados de Psiquiatria e Saúde Mental em Portugal [Internet]. 2019 [cited Jul 29]. Available from: https://www.dgs.pt/sm-organizacao.aspx Portuguese

26. Coordenação Nacional para a Saúde Mental. Documento de consenso para a Estrutura e Funções das Equipas de Saúde Mental Comunitária (ESMC) [Internet]. 2009 [cited 2020 Aug 16]. Available from: https://docplayer.com.br/112500998-Documentode-consenso-para-a-estrutura-e-funcoes-das-equipas-de-saudemental-comunitaria-esmc.html Portuguese

27. Administração Central Serviços Saúde. Guia de referenciação para as unidades e equipas de saúde mental da Rede Nacional de Cuidados Continuados Integrados [Internet]. Lisbon. 2017 [cited 2020 Aug 16]. Available from: http://www.fnerdm.pt/wp-content/ uploads/2018/05/Guia_Referenciacao_Final.pdf Portuguese

28. Jorge-Monteiro MF, Ornelas JH. "What's Wrong with the Seed?" A Comparative Examination of an Empowering CommunityCentered Approach to Recovery in Community Mental Health. Community Ment Health J. 2016 Oct;52(7):821-33. doi: 10.1007/ s10597-016-0004-8. Epub 2016 Apr 12. PMID: 27072950.

29. Narigão M. Rede Nacional de Cuidados Continuados Integrados e de Saúde Mental (RNCCl e RNCCISM). Paper presented at: ॥ Encontro Nacional IPSS Promotoras de Saúde [2nd National Encounter of Health Promoting Social Solidarity Institutions]. Confederação Nacional das Instituições de Solidariedade [National Confederation of Solidarity Institutions]; 2018 September 28; Fátima, Portugal.

30. Simões J, Augusto GF, Fronteira I, Hernández-Quevedo C. Portugal: Health system review. Health Systems in Transition [Internet], 2017 [cited 2020 Aug 16]; 19(2):1-184. Available from: https://www.euro. who.int/_data/assets/pdf_file/0007/337471/HiT-Portugal.pdf?ua=1 31. Ministério da Saúde, Despacho n 2753/2020 [Internet]. 2020; 200-202 [cited 2020 Aug 15]. Available from: https://dre.pt/ pesquisa/-/search/129678862/details/normal?l=1 Portuguese
32. Ministério da Saúde Gabinete do Secretátio de Estado Adjunto do Ministério da Saúde, Despacho n 2976/2014 [Internet]. 2014; 5402-5403. [cited 2020 Aug 3]. Available from: https://dre.pt/pesquisa/-/search/3162549/details/ normal?q=Despacho+n.\%C2\%BA\%202976\%2F2014 Portuguese

33. Ministério da Saúde. Rede de Referenciação Hospitalar. Psiquiatria da Infância e Adolescência [Internet]. 2018 [cited 2020 Aug 3]. Available from: https://www.sns.gov.pt/wp-content/ uploads/2018/06/RRH-Psiquiatria-da-Infância-e-da-AdolescênciaPara-CP.pdf Portuguese

34. Ministérios do Trabalho, Solidariedade e Segurança Social e Saúde. Portaria n68/2017 [Internet]. 2017 [cited 2020 Aug 17]. Available from: https://data.dre.pt/eli/port/68/2017/02/16/p/dre/ pt/html Portuguese

35. Administração Central dos Serviços de Saúde (PT), Comissão Técnica de Acompanhamento da Reforma de Saúde Mental. Relatorio do Grupo de Trabalho para avaliação da prestação de cuidados de saude mental e das necessidades na área da saúde mental [Internet]. Lisboa: Administração Central dos Serviços de Saúde (PT); 2015 [cited 2020 Aug 17]. Available from: http:// www.sg.min-saude.pt/NR/rdonlyres/EB54D9DC-8CD7-4249-A22698CF21D9B5D3/44008/Relatorio_Av_Prestacao_Cuidados_Saude_ Mental_2015.pdf Portuguese

36. Mateus $\mathrm{P}$, Caldas de Almeida J, M, de Carvalho Á, Xavier M: Implementing Case Management in Portuguese Mental Health Services: Conceptual Background. Port J Public Health 2017;35:1929. doi: $10.1159 / 000477646$

37. Perelman J, Chaves P, de Almeida JMC, Matias MA. Reforming the Portuguese mental health system: an incentive-based approach. Int J Ment Health Syst. 2018;12:25. doi: 10.1186/s13033-018-02044. PMID: 29853991; PMCID: PMC5975562.

38. Marques JG, Brissos S. Mental health in Portugal in times of austerity. Lancet Psychiatry. 2014 Sep;1(4):260. doi: 10.1016/ S2215-0366(14)70339-6. Epub 2014 Sep 10. PMID: 26360852.

39. Soares R, Pinto da Costa M. Experiences and Perceptions of Police Officers Concerning Their Interactions With People With Serious Mental Disorders for Compulsory Treatment. Front Psychiatry. 2019 Apr 18;10:187. doi: 10.3389/fpsyt.2019.00187. PMID: 31057433; PMCID: PMC6482210.

40. Pinto da Costa M, Guerra C, Malta R, Moura M, Carvalho S, Mendonça D. Psychiatry training towards a global future: trainees' perspective in Portugal. Acta Med Port. 2013 Jul-Aug;26(4):357-60. Epub 2013 Aug 30. PMID: 24016644.

41. Thornicroft G, Tansella M, Law A. Steps, challenges and lessons in developing community mental health care. World Psychiatry. 2008;7(2):87-92. doi: 10.1002/j.2051-5545.2008.tb00161.x. PMID: 18560483; PMCID: PMC2408397.

42. Bridges W. Managing Transitions: Making the Most of Change. 3rd ed. USA: Da Capo Lifelong Books; 2009. 